\title{
Incorporating Branded Academic Library Programming to Promote and Showcase Campus Research and Artistic Performances
}

$\mathrm{L}$ ibrary programming is an essential function of public libraries. On any given day, public libraries across the country are hosting a variety of programs for users of all ages and abilities. Programming connects users with public library staff, spaces, and materials. Historically, however, academic libraries have focused on the strength of their collections for connecting with users.

\section{What Others are Doing}

The Z. Smith Reynolds Library at Wake Forest University (WFU) incorporated branded library programming as one new area to emphasize our "third place" connection to campus. In seeking to know what other academic libraries have done regarding programming, it became clear that while academic libraries offer programming of a wide variety, ongoing programming

\section{6... academic libraries are proving their relevance to campus communities beyond being warehouses of knowledge.}

Presently, though, academic libraries are proving their relevance to campus communities beyond being warehouses of knowledge. Ray Oldenburg's concept of "third place" 1 inspired some to reframe the academic library to become their campus constituents' third place. Envisioning the library as a campus meeting place where everyone could come, listen, share and discuss ideas, current events, and one's research occurred simultaneously with library renovations that fostered group collaboration and study, casual spaces, and coffee shops. Bringing people into the building for more than the collections became a goal of many academic libraries, particularly those striving to maintain relevance in an ever-increasing digital knowledgebase. series were less common--at least as represented in published literature. This observation is confirmed by Timothy Hackman in his article about the creation of the University of Maryland Libraries' sponsored speaker series known as Speaking of Books... Conversations with Campus Authors. $\mathrm{He}$ states, "While the 'book talk' is a perennial favorite subject for public librarians, there is almost nothing published on the author talk in the academic library as a method of connecting with faculty." 2

Within the articles published on academic library lecture series, the authors commonly focused on lessons learned in planning, organizing, and successfully executing a successful library lecture event or series, as well as how these outreach initiatives help to integrate libraries more fully into the academic community of a university. ${ }^{3-10}$ As pointed out by Irene M. H. Herold, "nothing in library school or working as a front-line academic librarian provided preparation for event planning." 11

As organizers of two branded programs in an academic library, employees of the Z. Smith Reynolds Library (ZSR) present the following case study of the peaks and pitfalls of library programming, particularly in light of Herold's assessment that we were not, in fact, prepared for event planning in graduate school. Through nearly a decade of programmatic outreach, the logistics of coordinating and presenting a semesterly lecture series and annual student scholarship showcase have been honed.

\section{Branded Programming}

In 2004, Wake Forest University (WFU) hired a new library director who, shortly after her arrival, shared her desire for the ZSR Library to become more than just a place for students to study and a warehouse for books. One of her goals was to increase the Library's visibility on campus and to all of its constituents-administration, faculty, staff, and students. She envisioned ZSR as a campus meeting place where all are welcome to come and learn as well as share and discuss ideas, current events, and even one's personal research. In August 2005, a new Marketing Committee was established and charged with making that goal a reality. ${ }^{12}$ One idea presented by 
the committee was to host a series of lectures in ZSR, and with the director's approval, the committee moved forward. ${ }^{13}$

Eight lecture events and a musical performance by one of the University's all-male a cappella groups were hosted during the 2005-2006 academic year, and the response garnered, to what has now become known as the ZSR Library Lecture Series (ZSR LLS), was overwhelmingly positive and marked by excellent attendance from the Wake Forest community. ${ }^{14}$ It was not uncommon for members of the greater Winston-Salem community to be present in the audience. Due to its success, it was decided the ZSR LLS should continue the following academic year. In 2006-2007, ZSR Library's Marketing Committee sponsored and hosted 10 lecture series events. ${ }^{15}$

To reduce the load of the Marketing Committee, a separate Library Lecture Series Committee (LLSC) was formed in 2007. ${ }^{16}$ This new committee was given a new charge: "plan lectures and discussions that will support the current curriculum; address current issues and events; acknowledge and accentuate the current collection and bring together the many diverse points of view found in our community." 17

A second branded program at ZSR Library, the Senior Showcase, highlights exemplary undergraduate student research. Arising independently from the Library Lecture Series, the concept for the Senior Showcase was originally proposed by a WFU senior who wished to see greater recognition by the campus community for his fellow classmates' research. He believed the Library to be well-positioned to provide such recognition. Planning for the Showcase commenced in late January 2010, and the first annual Senior Showcase was presented in April 2010.

Support for the Senior Showcase grows each year, both in nominations and attendance. Each year, the pool of nominees includes representation from at least one new department, with 50 faculty from 23 departments nominating their students for the Showcase through 2015. Increasingly, the audience includes friends and family members of the selected students, in addition to WFU faculty and staff. The Provost, Vice Provost, Associate Provost for Research, and Dean of the College have attended, as well as the Dean and Associate Deans of the Library, lending invaluable administrative support to the Showcase program. The addition of the Library Auditorium has benefited the Showcase, as well as the Library Lecture Series, as it has provided a dedicated venue for both programs.

\section{Library Lecture Series: Logistics}

The number of ZSR Library employees on the LLSC varies, but typically six or seven individuals comprise its annual makeup, which includes a chair or two co-chairs appointed by ZSR Library's Associate Dean. When the LLSC began filming its lecture events as authorized by the speakers themselves, ZSR's Multimedia and Digital Production Services Coordinator became a permanent member of the LLSC. The Library's artistic Preservation Librarian, who designs and creates all publicity materials for the LLSC, has served as an ex-officio member since its beginning. Starting in 2010, the LLSC welcomed the Wake Forest Fellow, a paid internship position assigned to work in ZSR Library, as a new, standing member to its committee's roster.

Speakers who received an invitation from the LLSC to present on a specific topic or their recently published work or research have come from both the campus community (including students, faculty and staff) as well as the surrounding community of Winston-Salem and nearby localities. Most readily accepted the committee's invitation and appreciated the opportunity to share their knowledge in their areas of expertise. A few individuals declined their initial invitations to speak for various reasons, such as teaching abroad at one of WFU's overseas houses, taking a sabbatical, or even a prior commitment, but were willing to participate in the ZSR LLS the following semester. Notable participants have included Dr. Anthony Atala, Director of the Wake Forest Institute for Regenerative Medicine; Mike Riley, Chief Executive Officer and Editor in Chief of the Chronicle of Higher Education; and past North Carolina Poet Laureate, Joseph Bathanti.

As the popularity of the ZSR LLS has grown, the committee has been approached by individuals familiar with the series who would like to partner with the Library to present, for instance, a lecture about one of WFU's campus programs or a current exhibit. By partnering with the Library through the lecture series, these events received a level of exposure that they may not have had on their own.

Publicizing lectures has changed considerably from its beginnings. Press releases drafted by the lecture series committee for distribution to external media outlets, such as the WinstonSalem Journal, have been dropped due to changes in the external communication policy for the University. Today, lectures are promoted internally by means of email to the administrative assistants of all academic departments as well as library staff, paper flyers that are posted around campus by student assistants, a sandwich board in front of the Library, and postings to the University calendar and the Professional Development Center for the University. 
Programs for the lecture series have also been advertised through social media such as Facebook and Twitter. Additionally, bookmarks that include the lecture series' line-up for an entire semester are printed and distributed at all lectures and in specific locations throughout the Library.

Most events sponsored by the ZSR LLS have been traditional lectures, with individual presenters speaking about a subject in his or her area of expertise followed by a short question and answer period. However, other types of events have been hosted by the lecture series:

- Panel discussion. These have addressed specific topics with involvement by members from both inside and outside the WFU community, and have addressed current events as well as topics that could be deemed controversial. Topics for these discussions have included the Don't Ask, Don't Tell policy of the United States Armed Forces, food insecurity in Forsyth County, North Carolina, and the achievements made by women in the field of science and mathematics.

- Book signings. Several members of the WFU community as well as authors who were presenting in the Winston-Salem area have discussed their recently published books. A few of these have included book signings at the conclusion of the presentations, giving the audience a chance to purchase the book for themselves and to personally meet the author. Books have ranged from academic to mass marketed pressings, with a variety of authors including Emily Giffin, Lev Grossman, Joseph Bathanti, Deborah Harkness, Charlie Lovett, Shannon Gilreath, Gregory Parks, Blake Morant, and Margaret Supplee Smith.
- Art and performance. The visual arts have been represented by faculty in the Art Department, the director of the on-campus Charlotte and Philip Hanes Art Gallery, and staff from the nearby Reynolda House Museum of American Art. Musical performances have included faculty from the Music Department, a local jazz trio, and a bona fide local rock band who operated a music camp for children during the summer. There was even a live performance of the famed "balcony scene" from Shakespeare's Romeo and Juliet, with actors utilizing a portion of the Library's atrium while they delivered their lines.

The ZSR LLS has also included new types of events within its lineup as well as new methods of dissemination of its content such as streaming video for some of its events. The lecture series collaborated with other library committees to produce a one-day symposium called "The Big Disruption: The Coming Transformation of Higher Education." 18 Members of the LLSC used their collective experience to assist with the planning of the event and participation during the symposium itself.

\section{Budget}

Before 2012, the ZSR LLS operated without a budget, although this circumstance did not present any serious challenges to attracting potential speakers. In one sense, the University has lent itself as an unofficial "Speaker's Bureau." The LLS becomes not only a venue for faculty to publicize their research to the greater campus community, but also another means for faculty to add a service entry to their respective personal vitae. However, in one LLSC annual report to library administration, committee co-chairs remarked, "Although the lecture series was able to meet its goals with the programs for the 2010-2011 academic year, the committee has reached a plateau for what could be achieved without sources of funding. As a result, this prevents the committee from bringing in speakers who in turn could attract a larger audience." ${ }^{19}$ In response to these statements, ZSR Library's Dean (formerly titled director) earmarked a small amount of funds from the Friends of the Library account to be used at the discretion of the cochairs for expenses incurred (e.g. refreshments or speaker fees) by the ZSR LLS until continual funding was obtained. ${ }^{20}$

The nature of the lecture series has not been one where outside funding sources would be necessary. Because the speakers have been available on campus and in the surrounding area, their presentations were done on a volunteer basis with the recognition being an entry on their personal documentation. The ZSR LLS has not hosted any significant speakers outside of the campus community who have requested compensation for their appearances, so there has been no need to pursue any grant programs to sponsor a famous author or lecturer. However, this possibility could be explored with external programs, such as those sponsored by the American Library Association as mentioned in an article by Smith, Hunter and Eckwright or the National Endowment for the Humanities, if circumstances warranted that outcome. ${ }^{21}$

As previously mentioned, the ZSR LLS has hosted a few New York Times bestselling authors (e.g. Lev Grossman, Deborah Harkness) via the Authors in Schools \& Community program sponsored by Bookmarks, a local, nonprofit literacy organization which produces the annual Festival of Books and Authors held in Winston-Salem, North Carolina. ${ }^{22}$ Organizational 
connections made by several members of ZSR Library's staff, who are also Bookmarks' volunteers, allowed the Library the opportunity to provide a venue for a few of Bookmarks' sponsored book talks and signings.

\section{Challenges}

Along with its popularity, success, and longevity, the ZSR LLS has faced challenges in several areas: scheduling, speakers, planning the series, and space.

When the ZSR LLS began to promote itself as a series at the beginning of each semester, the previous methodology of event planning and scheduling of speakers had to change. The LLSC started thinking in terms of long-range planning (i.e. a semester in advance) as opposed to planning for a singular event whenever an opportunity for an event or idea presented itself. As a result, spring lecture series events were planned during the fall semester, and fall events were planned during the spring and sometimes even into the summer months. This long-range planning required committee members to regularly check the University's calendar, as new events are posted on a daily basis. Active participation by the LLSC is also needed on the day of lecture events in order to fulfill roles such as directing foot traffic, counting attendees, assisting with the needs of speakers, and recording events.

Most speakers, as mentioned before, have readily accepted the committee's invitation to speak and responded within a day or two regarding their availability. However, if the initial invitation generated no response from a potential speaker, then additional emails have followed in order to determine that speaker's interest to present at the lecture series. Should those subsequent emails remain unanswered, it has been understood that this inaction is essentially a "thanks, but no thanks" response from the potential speaker. Persistence often pays off with receiving a response from the potential speaker, but committee members have been mindful not to appear overbearing in a manner that would alienate the speaker from participating in the series entirely.

Wake Forest University's calendar is filled with a broad range of departmental and university sponsored events from which the campus community can choose to attend. Scheduling a date and time that has been convenient for a speaker without conflicting with other campus events can often be difficult. ZSR LLS sponsored events have been presented Monday through Friday, beginning between 2:00 p.m. and 5:30 p.m. On a rare occasion, the ZSR LLS has hosted a few lectures during the noon to 1 p.m. lunchtime hour. Flexibility is also key in scheduling lecture events because a speaker-or the Library or University-may have a conflict arise which necessitates rescheduling. Conflicts can often occur without any advanced warning, so contact with the speaker has been essential for accommodating these changes.

While there has been little difficulty in finding individual speakers, there have been challenges with coordinating a panel of speakers. Panel discussions can be especially difficult to schedule, as the event coordinator needs to find a specific date and time when all invited panelists are available to participate. Further, if one panelist is forced to cancel his or her appearance, it has been nearly impossible, in our experience, to find a replacement at a moment's notice. A panel's diminished size could also lead to underrepresentation of alternative viewpoints which could potentially create an unbalanced discussion. If this situation should occur, an acknowledgment regarding the absentee panelist should be given by the moderator before the panel discussion begins.

The issue of space was a huge challenge faced by the LLSC when scheduling lectures. Initially, three library venues were used for lectures, and each had its own set of problems. Inadequate space, seating, and furnishings as well as student displacement-these issues combined clearly demonstrated a need for a permanent and designated space where the ZSR LLS sponsored events could be held. Following graduation ceremonies in May 2011, construction of a 118-seat Library Auditorium commenced, alleviating all of the space issues faced by the LLSC. Opening that September, the ZSR LLS "had a permanent location to showcase its programming." 23

\section{Senior Showcase: Logistics}

Senior Showcase nominations are solicited from faculty in mid-February and submitted in mid-March. The extant list of faculty receiving the Library's e-newsletter is leveraged to disseminate the call for nominations. Nominations are submitted online, via a web form that includes free text fields for explanation.

In the nomination, faculty advisors speak to the originality of the work, the potential impact of the work upon the field, and the overall worthiness of the work to merit distinction. ${ }^{24}$ Students are notified of their nominations after the submission deadline has passed, and have one week to submit a copy of their work for review. The review panel consists of five library faculty, one for each division of the undergraduate College.

Reviewers evaluate submissions using three categories of criteria: Research, Presentation, and Impact. Under Research, works are assessed for their clear statement of purpose, evidence of thorough research, credible 
sources, and development of the idea. The Presentation criteria cover both written works — well-organized, wellwritten, and soundly reasoned-and artistic works - skills/aptitude, and interpretation-in recognition that honors projects from the Arts may be completed in a variety of mediums of expression. The final category, Impact, looks to the works' originality, creativity, and importance to the field, with emphasis on the strength of the faculty advisor's recommendation, summarizing the Impact criteria. From student submission to student notification, the review panel has approximately two weeks to review and assess all nominations.

The Showcase is coordinated by the Scholarly Communication Librarian, and became a part of this position's job responsibilities in the first year of the position's establishment at ZSR Library. As such, communications, reviewer recruitment, nominations and work submissions, meetings, and the Senior Showcase itself are all coordinated by one individual. Each year, the framework used for organizing Showcase logistics has been adjusted to streamline workflows, particularly with regard to the reviewers' time commitments to review meetings, and to ensure that the work required to host the Showcase remains manageable over the course of the spring semester. Although the Showcase is always held in mid-to-late April, planning commences in October with determining dates and recruiting reviewers.

\section{Budget}

The Senior Showcase began without a budget. As a student-initiated program, pitched to the Dean of the Library, the Showcase benefited from administrative support from inception, but in a library known for its entrepreneurial spirit, that support did not equate to a budget. A small amount of money was allocated toward refreshments for a reception following the Showcase, which were purchased at a local grocery store using a purchasing card from the University.

In the second year of the Showcase, the Undergraduate Research and Creative Activities Center of the University began sponsoring the reception that follows the Showcase, and assisting with ensuring the call for nominations reaches the attention of faculty working with undergraduate researchers. And since 2013, the Library has awarded each Showcase winner a $\$ 1,000$ prize in additional recognition of his or her accomplishment. ${ }^{25}$ Currently, the $\$ 5,000$ prize money is drawn from the Library's general budget. The hope is that the Senior Showcase will become an endowed program within the Library, ensuring the continued celebration of undergraduates' honors research.

\section{Challenges}

As with any program, the Senior Showcase is not without its share of challenges. One of the biggest challenges is timing, particularly working within a narrow timeframe between the nomination deadline and the decision deadline. Wake Forest University does not have an honors college or unified honors program; therefore, the requirements for undergraduate honors theses and projects vary across departments. This creates discrepancies in the number of eligible students in different disciplines. As was expected, some faculty have leveled criticism at the Showcase for the timeframe for eligibility. Reassuringly, though, other faculty offered constructive advice on how the Showcase timeframe could be adjusted to expand eligibility to more students and departments. The timeframe established for the Showcase will never fully accommodate all departments' schedules, which is an unfortunate reality; however, it is generally understood among faculty that the Showcase is striking the best possible balance between delaying the nomination deadline with giving the selected students sufficient time to prepare for a campus-wide presentation for which they were previously not expecting to present. Furthermore, student works do not have to be finalized in order to be considered, which expands eligibility to disciplines with late spring honors project deadlines.

Beyond knowingly constraining our potential field of nominees, the timing of the Showcase puts pressure on the reviewers to complete thorough reviews of an unknowable number of projects in 10 to 12 days. Students' works are due on a Friday, and final decisions are usually made by little more than a week later. Depending on the number of nominees, reviewers may need several hours to read and evaluate the body of student works. A two-to-three hour selection decision meeting is usually necessary to arrive at final decisions.

Timing during the academic year creates additional challenges for the Showcase. In order to enable the broadest possible nominee pool, nominations are not due until the Friday of spring break, which falls the second full week of March each year. Students have until the following Friday to submit their works for review. As the Showcase is normally held on the third Tuesday of April, which is a week to 10 days before the last day of classes, reviewers strive to give students at least three weeks to prepare their Showcase presentations, as students were not anticipating a campus-wide presentation in their study scheduling. The Tuesday afternoon, 3:00 p.m. start time for the Showcase generally reduces competition with other campus programs, but also limits the ability of 
faculty and students to attend, as many classes are held well into the afternoon. However, shifting to an evening program, or even a later afternoon program, would place the Showcase in greater competition for campus attendance.

\section{Conclusion}

The creation, success, and longevity of the Z. Smith Reynolds Library's branded library programming increases ZSR's visibility on Wake Forest University's campus and solidifies the Library as the "third place" of campus life, offering another venue for students, faculty, and staff to meet and interact around a unique framework of programming. Increases in programming budgets and participation by campus constituents attest to the importance and value of both branded programs. Additionally, the programs' brand recognition has aided in the fostering of partnerships with other campus departments, and has created opportunities for ZSR Library to work with units of the University outside of the traditional academic environment, positioning the Library as an outlet for the output of specific subjects to be presented to a much wider campus audience.

Tracked since the fall of 2009, over 3,000 individuals have attended ZSR LLS events, with the average lecture attracting an audience of at least 25 people. Eleven lectures were presented during the 2014-2015 academic year, bringing 455 people into the Library, with an additional 90 viewers through live-stream. Presentation and discussion of current, and at times controversial, topics and events in an academic context deepened the conversation for many attendees, broadening awareness and understanding of research conducted by Wake Forest faculty.

The Senior Showcase has also quickly gained recognition as a campuswide platform for highlighting the culminating scholarly experience of Wake Forest undergraduates. As the former ZSR Library Dean observed at the April 2014 Showcase, the Senior Showcase is the final stage of a threestep process of engaging new students with programs, helping students succeed in their studies through instruction, and celebrating their scholarly achievements as they prepare to graduate. ${ }^{26}$

Academic libraries continue to play vital, yet increasingly non-traditional, roles in fostering scholarship as well as assisting in the development of critical thinking skills through the purchasing, collecting, and instructional support of numerous resources for their campus constituents. The creation of branded programming by academic libraries that highlights the combined output of our faculty and student scholars further elevates and focuses attention on the foundational support of libraries, demonstrating how academic libraries continue to be essential centers of scholarship in our campus communities.

\section{References}

${ }^{1}$ Ray Oldenburg, The Great Good Place: Cafés, Coffee Shops, Community Centers, Beauty Parlors, General Stores, Bars, Hangouts and How They Get You Through the Day (New York: Paragon House, 1989).

${ }^{2}$ Timothy Hackman. "Speaking of books... connecting with faculty through a campus author series," Electronic Journal of Academic and Special Librarianship 10, no. 1 (2009), http://southernlibrarianship.icaap.org.go.libproxy.wakehealth. edu/content/v10n01/hackman_t01.html (accessed August 23, 2014).

${ }^{3}$ Carole Ann Fabian and others. "Multiple models for library outreach initiatives," The Reference Librarian 39, no. 82 (2003), doi:10.1300/J120v39n82_04, http://search.ebscohost.com/login.aspx?direct=true\&db=aph\&AN=127988 26\&site=ehost-live (accessed September 6, 2014).

${ }^{4}$ Irene M. H. Herold. "Planning and executing an annual library lecture," Library Administration \& Management 20, no. 3 (2006): 131-134. http://search.ebscohost.com/login. aspx?direct=true\&db=llf\&AN=502888173\&site=eho st-live (accessed August 23, 2014).

${ }^{5}$ Michele C. Russo and Nancy Wootton Colborn. "Something for (almost) nothing: public relations on a shoestring in an academic library," Library Administration \& Management 16, no. 3 (2002): 138-145. http://search.ebscohost. com/login.aspx?direct=true\&db=llf\&AN=502883323\&site=ehost-live (accessed August 23, 2014).

${ }^{6}$ Justine Cotton and Heather Pfaff. "The secret lives of professors: connecting students with faculty research through a faculty lecture series,” Feliciter 55, no. 6 (2009): 254-256. http://go.libproxy.wakehealth.edu/login?url=http:// search.ebscohost.com/login.aspx? direct=true\&db=llf\&AN=502970635\&site=ehost-live (accessed August 23, 2014).

7 "Case study: University of Texas at Arlington, Arlington, TX," in Library Success: A Celebration of Library Innovation, Adaptation and Problem Solving, ed. Leslie Edmonds Holt, Glen Holt, and Stratton Lloyd (Ipswich, MA: Ebsco, 2006), 100-102. http://search.ebscohost.com/login.aspx?direct=true\&db=lih\&AN=30063607\&site=ehost-live (accessed August 23, 2014). 
${ }^{8}$ Cathy Carpenter. "Transforming the Georgia Tech Architecture Library into a social space," Art Documentation: Bulletin of the Art Libraries Society of North America 30, no. 1 (2011): 79-83. http://search.ebscohost.com/login.as px?direct=true\&db=llf\&AN=503013562\&site=ehost-live (accessed August 23, 2014).

${ }^{9}$ Catherine Soehner, Christy Hightower, and Wei Wei. "Changing mission, strengthened focus: a new use for the current periodicals room at the University of California, Santa Cruz," Issues in Science \& Technology Librarianship no. 44 (2005), doi:10.5062/F48913T2, http://www.istl.org/05-fall/article2.html (accessed August 23, 2014).

${ }^{10}$ Rochelle Smith, Ben Hunter, and Gail Z. Eckwright. "Open house in the ivory tower: public programming at an academic library," Electronic Journal of Academic and Special Librarianship 10, no. 2 (2009), http://southernlibrarianship. icaap.org.go.libproxy.wakehealth.edu/content/v10n02/smith_r01.html (accessed August 23, 2014).

${ }^{11}$ Herold, 134.

${ }^{12}$ Renate Evans. “'O This Learning, What a Thing It Is!,” Library Gazette 18, no. 4 (2006): 7-8. http://zsr.wfu.edu/ files/library-gazette-2006.pdf (accessed June 18, 2014).

${ }^{13}$ Mary Scanlon (Research and Instruction Librarian for Business and Economics, former Chair of Z. Smith Reynolds Library Marketing Committee), in discussion with co-author Carolyn McCallum, June 18, 2014 in Z. Smith Reynolds Library, Winston-Salem, NC.

${ }^{14}$ Evans, 8.

${ }^{15}$ ZSReads newsletter (Fall 2006) http://zsr.wfu.edu/term/zsreads-fall-2006/ (accessed September 13, 2014); ZSReads newsletter (Winter 2007) http://zsr.wfu.edu/term/zsreads-winter-2007/ (accessed September 13, 2014).

${ }^{16}$ Scanlon discussion.

17 “Library Committees." http://zsr.wfu.edu/about/committees/ (accessed July 16, 2014).

18 "Future of Higher Education Symposium-The Big Disruption: The Coming Transformation of Higher Education," http://zsr.wfu.edu/outreach/future-of-higher-ed/ (accessed September 18, 2014).

${ }^{19}$ Christian Burris, e-mail message with attachment "LLS 2010-2011 Annual Report" written by Christian Burris and Carolyn McCallum to Carolyn McCallum, September 28, 2012.

${ }^{20}$ Lynn Sutton, e-mail message to Kristen Morgan, Christian Burris, Carolyn McCallum, Wanda Brown, and Susan Smith, June 17, 2012.

${ }^{21}$ Smith, Hunter, and Eckwright, http://southernlibrarianship.icaap.org.go.libproxy.wakehealth.edu/content/v10n02/ smith_r01.html

22 "Authors In Schools \& Community." http://bookmarksnc.org/authors-in-schools (accessed March 23, 2016).

${ }^{23}$ Christian Burris, e-mail message with attachment "LLS 2011-2012 Annual Report" written by Christian Burris and Carolyn McCallum to Wanda Brown, Susan Smith, Lynn Sutton and Carolyn McCallum, June 15, 2012.

24 “Senior Showcase," Z. Smith Reynolds Library website, http://zsr.wfu.edu/events/senior-showcase/, (accessed July 15, 2014).

25 "Highlights from the Fourth Annual Senior Showcase." ZSReads newsletter (Summer 2013), http://zsr.wfu.edu/2013/ highlights-from-the-fourth-annual-senior-showcase/, (accessed July 15, 2014).

${ }^{26}$ Hubert David Womack, Susan Sharpless Smith, and Mary Beth Lock. "Large-scale, live-action gaming events in academic libraries: how and why," College \& Research Libraries News 76, no. 4 (2015): 210-214. http://crln.acrl.org/ content/76/4/210.full (accessed June 30, 2015).

\section{Selected Bibliography}

Bookmarks, "Authors In Schools \& Community," http://bookmarksnc.org/authors-in-schools.

Carpenter, Cathy. "Transforming the Georgia Tech Architecture Library into a social space," Art Documentation: Bulletin of the Art Libraries Society of North America 30, no. 1 (2011): 79-83. http://search.ebscohost.com/login.aspx?direct $=$ true $\& \mathrm{db}=11 \mathrm{f} \& \mathrm{AN}=503013562 \&$ site=ehost-live (accessed August 23, 2014).

"Case study: University of Texas at Arlington, Arlington, TX," in Library Success: A Celebration of Library Innovation, Adaptation and Problem Solving, edited by Leslie Edmonds Holt, Glen Holt, and Stratton Lloyd, 100-102. Ipswich, MA: Ebsco, 2006. http://search.ebscohost.com/login.aspx?direct=true\&db=lih\&AN=30063607\&site=ehost-live (accessed August 23, 2014).

Cotton, Justine, and Heather Pfaff. "The secret lives of professors: connecting students with faculty research through a faculty lecture series,” Feliciter 55, no. 6 (2009): 254-256. http://search.ebscohost.com/login.aspx?direct=true\&d 
$\mathrm{b}=1 \mathrm{ff} \& \mathrm{AN}=502970635 \&$ site=ehost-live (accessed August 23, 2014).

Evans, Renate. “'O this learning, what a thing it is!,” Library Gazette 18, no. 4 (2006): 7-8. https://zsr.wfu.edu/files/ library-gazette-2006.pdf (accessed June 18, 2014).

Fabian, Carole Ann, Charles D’Aniello, Cynthia Tysick, and Michael Morin. "Multiple models for library outreach initiatives," The Reference Librarian 39, no. 82 (2003). http://search.ebscohost.com/login.aspx?direct=true\&db=ap h\&AN=12798826\&site=ehost-live (accessed September 6, 2014).

Hackman, Timothy. "Speaking of books... connecting with faculty through a campus author series. Electronic of Academic or Special Librarianship 10, no.1 (Spring 2009). http://southernlibrarianship.icaap.org.go.libproxy. wakehealth.edu/content/v10n01/hackman_t01.html (accessed August 23, 2014)

Herold, Irene M. H. "Planning and executing an annual library lecture." Library Administration \& Management 20, no. 3 (2006): 131-134. http://search.ebscohost.com/login.aspx?direct=true\&db=llf\&AN=502888173\&site=eho st-live (accessed August 23, 2014)

"Highlights from the Fourth Annual Senior Showcase." ZSReads newsletter (Summer 2013), http://zsr.wfu.edu/2013/ highlights-from-the-fourth-annual-senior-showcase/ (accessed July 15, 2014).

“Library Lecture Series," ZSReads newsletter (Winter 2007) http://zsr.wfu.edu/term/zsreads-winter-2007/ (accessed September 13, 2014).

Oldenburg, Ray. The Great Good Place: Cafés, Coffee Shops, Community Centers, Beauty Parlors, General Stores, Bars, Hangouts and How They Get You Through the Day. New York: Paragon House, 1989.

Russo, Michele C., and Nancy Wootton Colborn. "Something for (almost) nothing: public relations on a shoestring in an academic library," Library Administration \& Management 16, no. 3 (2002): 138-145. http://search.ebscohost. com/login.aspx?direct=true\&db=llf\&AN=502883323\&site=ehost-live (accessed August 23, 2014).

Scanlon, Mary. 2014. Interview by Carolyn McCallum. June 18. Z. Smith Reynolds Library, Winston-Salem, NC.

Smith, Rochelle, Ben Hunter, and Gail Z. Eckwright. "Open house in the ivory tower: public programming at an academic library," Electronic Journal of Academic and Special Librarianship 10, no. 2 (Summer 2009), http:// southernlibrarianship.icaap.org.go.libproxy.wakehealth.edu/content/v10n02/smith_r01.html (accessed August 23, 2014).

Soehner, Catherine, Christy Hightower, and Wei Wei. "Changing mission, strengthened focus: a new use for the current periodicals room at the University of California, Santa Cruz," Issues in Science \& Technology Librarianship no. 44 (2005), doi:10.5062/F48913T2, http://www.istl.org/05-fall/article2.html (accessed August 23, 2014).

“2006-07 Library Lecture Series," ZSReads newsletter (Fall 2006) http://zsr.wfu.edu/term/zsreads-fall-2006/ (accessed September 13, 2014).

Womack, Hubert David, Susan Sharpless Smith, and Mary Beth Lock. "Large-scale, live-action gaming events in academic libraries: how and why," College \& Research Libraries News 76, no. 4 (2015): 210-214. http://crln.acrl.org/ content/76/4/210.full (accessed June 30, 2015).

Z. Smith Reynolds Library, "Future of Higher Education Symposium-The Big Disruption: The Coming Transformation of Higher Education," http://zsr.wfu.edu/outreach/future-of-higher-ed/.

Z. Smith Reynolds Library, "Library Committees," http://zsr.wfu.edu/about/committees/.

Z. Smith Reynolds Library, “Senior Showcase,” http://zsr.wfu.edu/events/senior-showcase/.

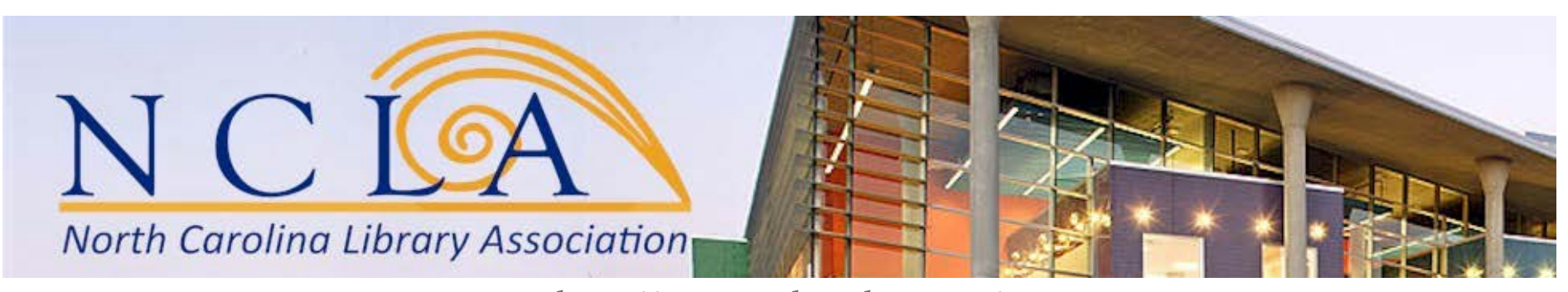

http://www.nclaonline.org/ 